\title{
New localities and distribution models inform the conservation status of the endangered lizard Anolis guamuhaya (Squamata: Dactyloidae) in central Cuba
}

Tomás M. Rodríguez-Cabrera, ${ }^{1}$ Javier Torres, ${ }^{2}$ Carlos A. Mancina, ${ }^{3}$ Ruben Marrero, ${ }^{1}$ Yasel U. Alfonso, ${ }^{4}$ and Ernesto Morell Savall ${ }^{5}$

${ }^{1}$ Sociedad Cubana de Zoología. La Habana, Cuba. E-mails: tomasmichel.rodriguez@gmail.com, rubensherp89@gmail.com.

${ }^{2}$ Department of Ecology and Evolutionary Biology, University of Kansas. Lawrence, Kansas 66045, USA. E-mail: javiertorres@ ku.edu.

${ }^{3}$ División de Zoología de Vertebrados, Instituto de Ecología y Sistemática. La Habana, Cuba. E-mail: mancina@ecologia.cu.

${ }^{4}$ Florida Museum of Natural History, Division of Herpetology, University of Florida. Gainesville, Florida 32611, USA. E-mail: anoles1983cuba@gmail.com.

${ }^{5}$ Edificio 4, Apto 7, e/ Oquendo y Silverio, Rpto Virginia, Santa Clara, Villa Clara 50100, Cuba. E-mail: ernestomorell68@ nauta.cu.

\begin{abstract}
New localities and distribution models inform the conservation status of the endangered lizard Anolis guamuhaya (Squamata: Dactyloidae) from central Cuba. Anolis guamuhaya is known from seven localities restricted to the Guamuhaya Massif in central Cuba and is always associated with mountane ecosystems above $300 \mathrm{~m}$ a.s.l. Previous evaluations of the conservation status of the species based on the estimated number of mature individuals have categorized the anole as Endangered. Eight new records of A. guamuhaya are provided here. These double the number of known localities, and two represent the first records of the species in lowland areas, apart from the Guamuhaya Massif. The new records extend the elevational range of the species from 15 $\mathrm{m}$ to above $1000 \mathrm{~m}$. We used ecological niche modeling based on all of the locality records, along with what we considered the most appropriate IUCN criteria according to the available information (Criterion B) to reevaluate the conservation status of the species. These new records of A. guamuhaya increase its area of occupancy up to a total of $60 \mathrm{~km}^{2}$, and its extent of occurrence up to $648 \mathrm{~km}^{2}$. Despite this increase in geographic range, the species meets the IUCN criteria in the category of Endangered. We used ecological niche modeling to predict possible trends for the species under differing scenarios of global climate change, all of which portend a drastic reduction in area climatically suitable for A. guamuhaya.
\end{abstract}


Keywords: Climate change, ecological niche modeling, natural history, Twig-giant Anole, West Indies.

\begin{abstract}
Resumen
Nuevas localidades y modelos de distribución informan sobre el estatus de conservación del lagarto amenazado Anolis guamuhaya (Squamata: Dactyloidae) de Cuba central. Anolis guamuhaya se conoce de siete localidades restringidas al Macizo de Guamuhaya, en Cuba central, siempre asociado a ecosistemas de montaña por encima de los $300 \mathrm{~m}$ s.n.m. Evaluaciones anteriores de su estatus de conservación basadas en el número estimado de individuos maduros categorizaron a la especie En Peligro. En este trabajo damos a conocer ocho nuevos registros de A. guamuhaya. Con estos se duplica el número de localidades conocidas y dos de ellas constituyen los primeros registros de esta especie en zonas llanas, fuera del Macizo de Guamuhaya. Estos nuevos registros expanden el rango altitudinal de la especie desde $15 \mathrm{~m}$ hasta por encima de los $1000 \mathrm{~m}$. Teniendo en cuenta los registros previos y los nuevos, hacemos una reevaluación del estatus de conservación de la especie empleando la modelación de nicho ecológico y los criterios de la UICN que consideramos más apropiados de acuerdo a la información disponible (criterio B). Estos nuevos registros de A. guamuhaya aumentan su área de ocupación hasta un total de $60 \mathrm{~km}^{2}$ y su extensión de presencia hasta $648 \mathrm{~km}^{2}$. A pesar de este incremento en su área de distribución, la especie se ajusta a los criterios de la UICN para la categoría de En Peligro. Usamos la modelación de nicho ecológico para predecir posibles tendencias de la especie bajo diferentes escenarios de cambio climático, donde todos los modelos auguran una reducción drástica del área climáticamente idónea para la especie.
\end{abstract}

Palabras claves: cambio climático, ecomorfo gigante de ramita, historia natural, modelación de nicho ecológico, Las Antillas.

\title{
Resumo
}

Novas localidades e modelos de distribuição informam sobre o estado de conservação do lagarto Anolis guamuhaya (Squamata: Dactyloidae) de Cuba central. Anolis guamuhaya é conhecida de sete localidades restritas ao Maciço de Guamuhaya, no centro de Cuba, sempre associada a ecossistemas montanhosos acima de $300 \mathrm{~m}$ de altitude. Avaliações anteriores de seu estado de conservação baseadas no número estimado de indivíduos maduros categorizaram a espécie como Em Perigo. Neste trabalho, fornecemos oito novos registros de A. guamuhaya. Com esses registros, duplica-se o número de localidades conhecidas, e duas delas constituem os primeiros registros da espécie em zonas baixas fora do Maciço de Guamuhaya. Os novos registros expandem a amplitude altitudinal da espécie desde $15 \mathrm{~m}$ até acima dos $1000 \mathrm{~m}$. Levando em conta os registros prévios e os novos, reavaliamos o estado de conservação da espécie empregando modelagem de nicho ecológico e os critérios da IUCN que consideramos mais apropriados de acordo com a informação disponível (Critério B). Os novos registros de A. guamuhaya aumentam sua área de ocupação para um total de $60 \mathrm{~km}^{2}$ e sua extensão de presença para $648 \mathrm{~km}^{2}$. Apesar desse incremento em sua área de distribuição, a espécie ajusta-se aos critérios da IUCN para a categoria Em Perigo. Utilizamos modelagem de nicho ecológico para prever possíveis tendências para a espécie em diferentes cenários de mudanças climáticas globais, todas pressagiando uma redução drástica em sua área climática adequada.

Palavras-chave: anoles-graveto-gigante, Antilhas, história natural, modelagem de nicho ecológico, mudanças climáticas. 


\section{Introduction}

There are six species of anoles in the Chamaeleolis clade, all endemic to Cuba (Rodríguez et al. 2013, Poe et al. 2017). These large (154-177 mm snout-vent length), slowmoving, chameleon-like anoles have massive heads with prominent parietal bones that form a casque-like structure, and posterior molariform teeth that may enable the lizards to consume hard prey, such as gastropod mollusks (Garrido and Schwartz 1968, Díaz et al. 1998, Herrel and Holanova 2008). Among the morphological adaptations of these lizards for a strict arboreal lifestyle and use of narrow perches are a semiprehensile, non-autotomous, blunt tail and short limbs (Garrido and Schwartz 1968, Garrido 1982, Rodríguez 1999). Given the striking differences of these anoles from their congeners, they were placed in their own genusChamaeleolis (e.g., Garrido and Schwartz 1968, Garrido 1982, Rodríguez 1999). However, Chamaeleolis currently is considered a junior synonym of Anolis because it is nested within the Anolis radiation (Hass et al. 1993, Jackman et al. 1999, Poe 2013, Pyron et al. 2013, Poe et al. 2017).

Anolis guamuhaya (Garrido, Pérez-Beato, and Moreno, 1991) is a montane twig-giant anole currently thought to be restricted to ecosystems above $300 \mathrm{~m}$ a.s.l. in the Guamuhaya Massif (= Escambray) (e.g., Garrido et al. 1991, Rodríguez et al. 2013). The massif is located in south-central Cuba and is composed of two main topographical units - the Trinidad Range in the west (the largest unit) and the Sancti Spíritus Range in the east (the smallest unit); the Agabama River Basin separates these mountain ranges (Mateo-Rodríguez and Acevedo-González 1989; Figure 1). Garrido et al. (1991) stated that the holotype of A. guamuhaya was collected on the road between Jibacoa and Topes de Collantes, Trinidad Range, at about $900 \mathrm{~m}$ a.s.l. However, the highest elevations between these two localities is $869 \mathrm{~m}$ a.s.l. at Sierra Guaniquical (4 $\mathrm{km}$ SSW Jibacoa) and $851 \mathrm{~m}$ a.s.l. at Loma
Guaniquical (6 km SSE Jibacoa), and the road does not exceed $800 \mathrm{~m}$ a.s.l. at any point. Elevations of $900 \mathrm{~m}$ near to the type locality of A. guamuhaya occur only at Pico de Potrerillo (973 m a.s.l., $3.3 \mathrm{~km}$ SE Topes de Collantes) and Pico Tuerto (919 m a.s.1., $4.3 \mathrm{~km}$ WSW Jibacoa, western side of Hanabanilla Dam). Access to cartographic maps and GPS was limited when Garrido et al. (1991) described this species, and in interviews with Orlando H. Garrido, we could not confirm the exact collecting site of the holotype. Therefore, according to the International Code of Zoological Nomenclature (ITZN 1999; Article 76), the type locality of $A$. guamuhaya includes the entire strip of road between Jibacoa and Topes de Collantes (about $22 \mathrm{~km}$ ). Additional specimens were collected at Topes de Collantes and surrounding areas, Sancti Spíritus Province (Garrido and Schwartz 1968, Garrido et al. 1991, Rodríguez et al. 2013), and in the vicinity of Aguacate, Cienfuegos Province (Garrido 1982, Garrido et al. 1991). The adult male collected by Wilson (1957) at Mina Carlota, Cienfuegos Province, was initially assigned to $A$. porcus (Cope, 1864) by Garrido and Schwartz (1968) and later to A. guamuhaya by Garrido et al. (1991). Most recently, Torres et al. (2015) reported the species from near Pico San Juan (at 1015 m a.s.l.), Cienfuegos Province.

The detectability of species is sometimes a critical factor in estimating population density and other demographic parameters (e.g., Mancina and Cruz 2017). The coloration and behavior of twig-giant anoles are highly effective in camouflaging the lizards (Garrido and Schwartz 1968, Leal and Losos 2000). Because it is so difficult to detect them by day, we assume that the lizards are more abundant than they seem to be. Nevertheless, the conservation status of some species in the Chamaeleolis clade, including $A$. guamuhaya, has been evaluated based only on the IUCN Criterion D, which refers to the estimated number of mature individuals (IUCN 2001, 2012, IUCN Standards and Petitions Subcommittee 2014). Rodríguez (1999, 2012) listed A. guamuhaya as Endangered; however, 


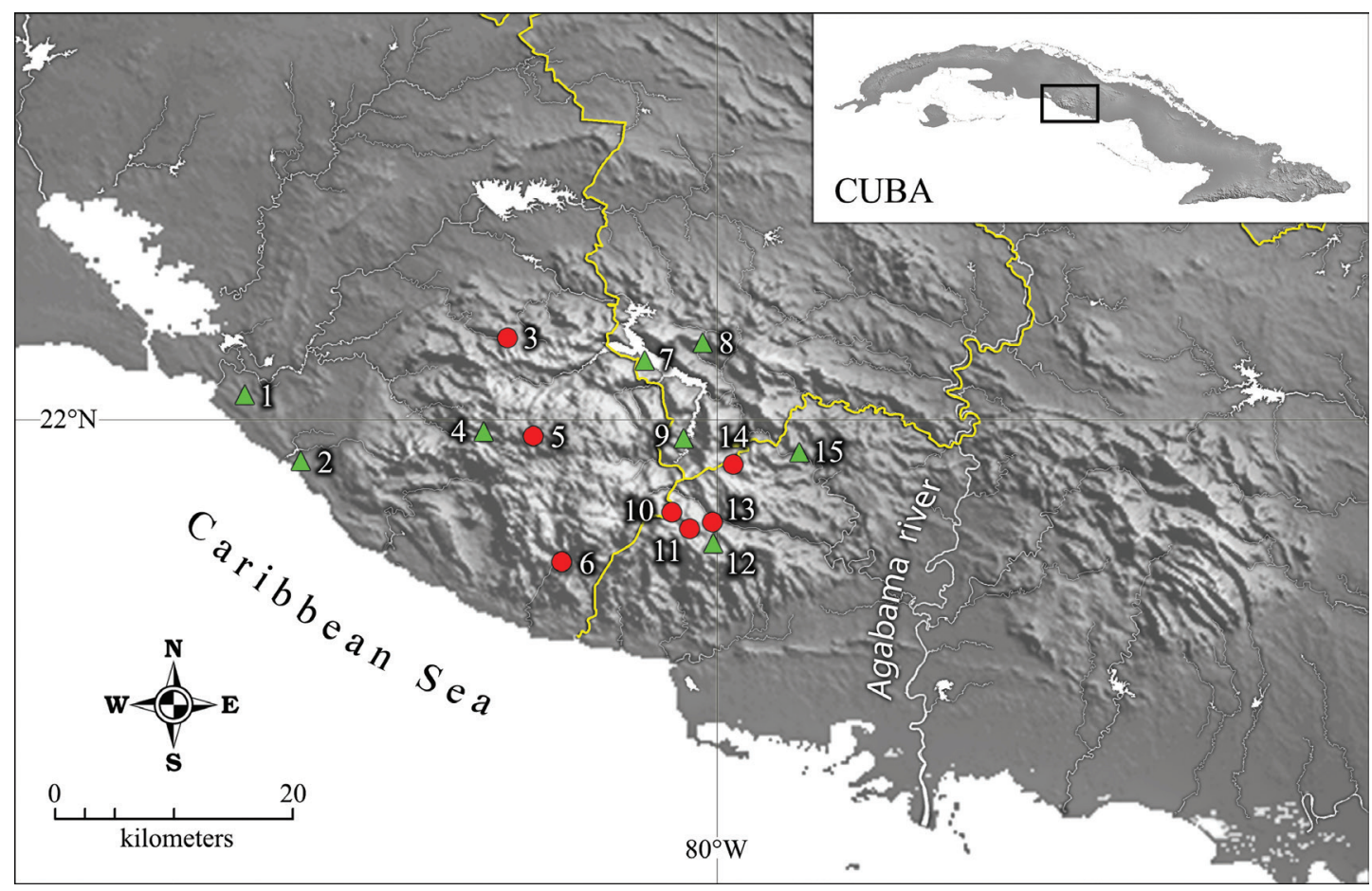

Figure 1. Distribution of Anolis guamuhaya in south-central Cuba with locality records from the literature (red dots) and this study (green triangles): (1) Santa Martina, (2) Boca Ambuila, (3) Mina Carlota, (4) Carso de Buenos Aires, (5) Pico San Juan, (6) ca. 6 km SW of Aguacate, (7) Río Negro Touristic Center, (8) Loma Cariblanca, (9) Trinitario Stream waterfall, (10) La Chispa, (11) Topes de Collantes and vicinity, (12) Vegas Grandes, (13) Caburní waterfall, (14) midway on the road between Jibacoa and Topes de Collantes, and (15) resurgence of the Jibacoa River. Note the two main topographical units that form the Guamuhaya Massif (the Trinidad Range in the west and the Sancti Spíritus Range in the east), divided by the Agabama River Basin.

this author commented that the population size of the species was unknown and that all records were restricted to a region of about $14 \mathrm{~km}^{2}$ in the Sancti Spíritus Province, with a calculated area of occupancy of $8 \mathrm{~km}^{2}$. Also, this author overlooked two localities from Cienfuegos Province-Mina Carlota, and ca. $6 \mathrm{~km} \mathrm{SW}$ of Aguacate (Wilson 1957, Garrido and Schwartz 1968, Garrido 1982, Garrido et al. 1991). However, the reclusive habits and camouflage of twig-giant anoles (e.g., Garrido and Schwartz 1968, Leal and Losos 2000) make it extremely difficult to estimate population size accurately by counting in searches by day, in contrast to gathering data for other more conspicuous anoles (e.g., trunk-ground anoles). Thus, we consider that the population size of A. guamuhaya may be substantially greater than estimates based on Criterion D suggest.

The Guamuhaya Massif has been intensively and extensively deforested, particularly during the last two centuries (e.g., Domínguez-González and Acosta-Rodríguez 2012, Mancina et al. 2017). Given the highly arboreal habits of twiggiant anoles, the loss of forest coverage probably has had negative effects on the population of $A$. guamuhaya. Herein we report more than twice the number of localities previously known for 
the species and reevaluate its conservation status applying what we consider the most appropriate IUCN criteria according to the available information and taking into account the behavioral particularities of twig-giant anoles. We used ecological niche modeling to test the possible response of A. guamuhaya to the effects of different future scenarios of global climate change. Last, we discussed implications for the conservation of the species.

\section{Materials and Methods}

\section{Data Collection}

The specimens of A. guamuhaya reported here were collected between 1993 and 2014; additional surveys were conducted until late-2018. Two methods were effective in detecting these lizards. In the first, small groups composed of two to five people separated by about $2 \mathrm{~m}$ from one another walk in line across the forest by day. When a lizard tries to hide from the first person by moving to the opposite side of the trunk or branch, it is more likely to be seen by the next person. The second method, with which we obtained the best results, is searching at night when the anoles are sleeping; by night, the twig-giant anoles are whitish in color, and therefore, easily detectable in darkness in the white light of a headlamp. It is necessary to check all vegetation strata, because these anoles may be found sleeping as low as 50 $\mathrm{cm}$ above the ground on shrubby vegetation and vines to more than $5 \mathrm{~m}$ high in the canopy (Leal and Losos 2000, authors pers. obs.).

We included seven literature records (Rodríguez et al. 2013, Torres et al. 2015) and eight new localities of $A$. guamuhaya in our analyses (Figure 1; Appendix I). To include the holotype record in this study, we assigned its locality to a point midway on the road between Jibacoa and Topes de Collantes (Figure 1). We collected geographic coordinates directly in the field with a GPS Garmin eTrex Vista HC or obtained them from MapInfo Professional ver. 10.5. Datum for all coordinates is WGS 84 . We also accessed existing GIS data available for voucher specimens deposited in several collections. Specimens were collected under the project "Colecciones zoológicas, su conservación y manejo II," hosted by the Instituto de Ecología y Sistemática and deposited in the zoological collection of the latter institution and the Museo de Historia Natural "Felipe Poey" (Appendix I). Acronyms and abbreviations are as follow: SVL $=$ snout-vent length, $\mathrm{TL}=$ tail length; CZACC: Instituto de Ecología y Sistemática, La Habana; MFP: Museo de Historia Natural "Felipe Poey", Facultad de Biología, Universidad de La Habana, La Habana; MNHNCu: Museo Nacional de Historia Natural de Cuba, La Habana; MCZ: Museum of Comparative Zoology, Harvard University, Cambridge, Massachusetts, USA; USNM: National Museum of Natural History, Smithsonian Institution, Washington D.C., USA; NMP: National Museum of Prague, Czech Republic.

For the purposes of this work and following the concept of "location" of the IUCN Standards and Petitions Subcommittee (2014; section 4.11), we considered all locality records separated by less than $2 \mathrm{~km}$ to be the same location (e.g., Topes de Collantes and vicinity; Garrido and Schwartz 1968, Garrido 1982, Rodríguez et al. 2013; Appendix I) and provided a central reference coordinate and elevation. After applying this criterion, the 32 records of $A$. guamuhaya represent 15 different locations, eight of which are new ones reported here (Figure 1; Appendix I). For the reevaluation of the conservation status we used the IUCN Criterion B (IUCN 2001, 2012, IUCN Standards and Petitions Subcommittee 2014).

\section{Ecological Niche Modeling}

Occurrence and study region.-We constructed Ecological Niche Models (ENMs) of $A$. guamuhaya with the maximum entropy algorithm Maxent (v.3.3.3; Phillips et al. 2006). Maxent examines the relationship between known occurrence records of the species and the 
environmental characteristics of that area, and then extrapolates from the areas where similar conditions occur in the study region (Phillips and Dudik 2008). We defined the study region for model calibration using a convex hull that enclosed the occurrence records, and then buffered this at a distance of $50 \mathrm{~km}$ (Figure 2). We considered this extent appropriate as background selection because it does not include large regions that the species does not inhabit

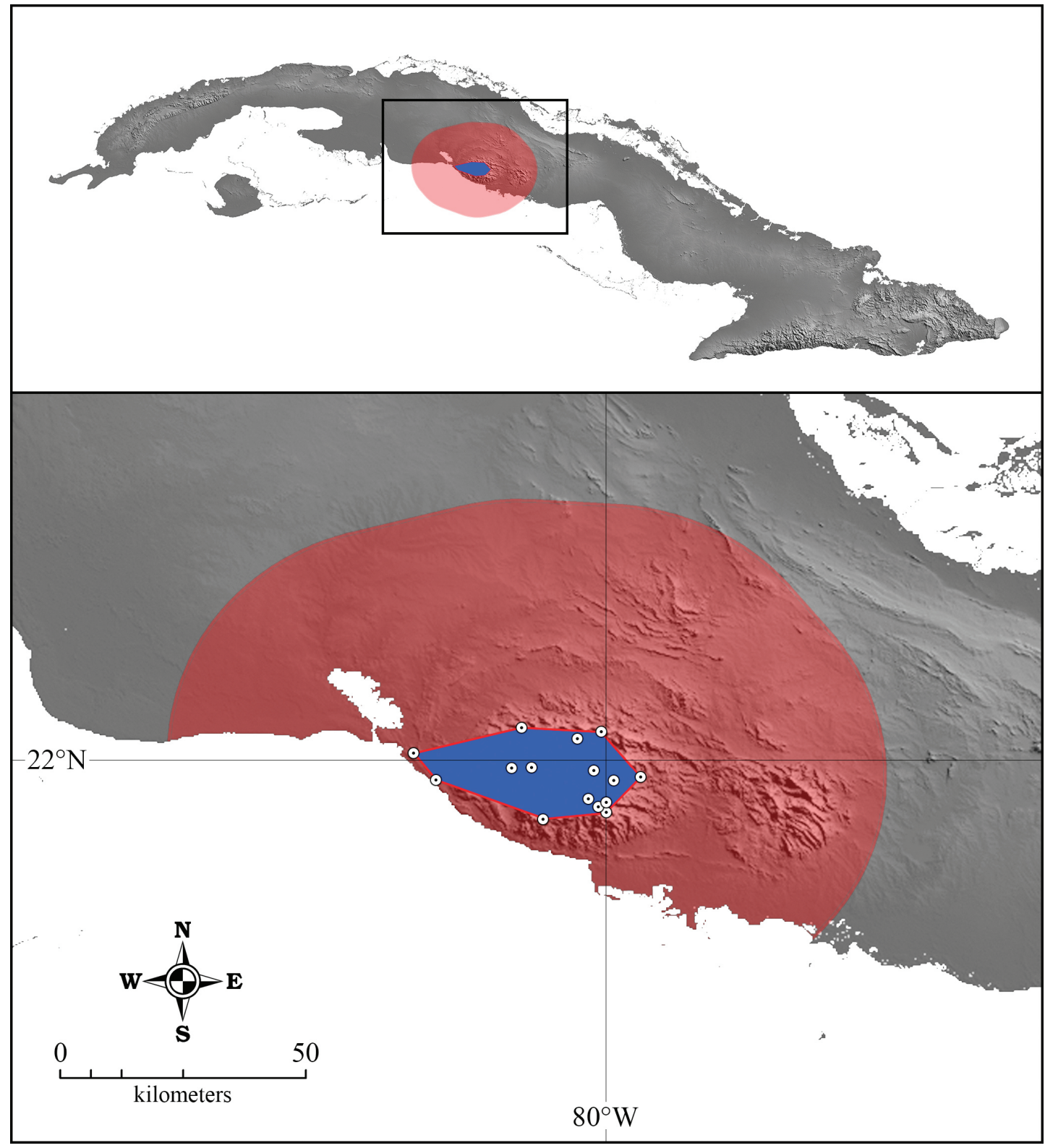

Figure 2. Geographical extent (white dots), convex hull (blue polygon) and background sampling (red area) considered in this study. 
owing to dispersal limitations and/or biotic interactions, such as competition with similar species (Barve et al. 2011, Anderson and Raza 2010). We extracted climate information using ArcGIS v. 10.3 (ESRI, Redlands) and ran the model by randomly sampling 5000 background points within this extent.

Environmental variables and climatic scenarios.-As current and future predictor variables, we used 19 bioclimatic variables with a resolution of ca. $1 \mathrm{~km}^{2}\left(0.74 \mathrm{~km}^{2}\right.$ for Cuba) downloaded from the WorldClim ver. 1.4 database (http://www.worldclim.com) (Hijmans et al. 2005). We first ran a model in MaxEnt ver. 3.3.3k (Phillips et al. 2006), including all variables, to identify those with the highest significance to the model and selected the bioclimatic predictors from the jackknife test of variable importance. We selected six variables with low collinearity (Pearson's $r<0.8$ ) that could be ecologically important to reptiles, as follow: mean diurnal temperature range (Bio 2); temperature seasonality (Bio 4); maximum temperature of warmest month (Bio 5); precipitation of wettest month (Bio 13); seasonality of precipitation (Bio 15); and precipitation of driest quarter (Bio 17). The use of more predictors could generate overfitting and could reduce temporal transfer (Peterson et al. 2011, Anderson 2013, Radosavljevic and Anderson 2014).

Our prediction is based on bioclimatic envelope modeling, which changes with coupled 10 general circulation models (GCMs): BCCCSM1-1, CCSM4, CNRM-CM5, HadGEM2-ES, MIROC5, MPI-ESM-LR, MRI-CGCM3, GISSE2-R, NorESM1-M, IPSL-CM5A. Different GCMs and greenhouse gas scenarios will lead to various changes in distributions of species in the future. The Intergovernmental Panel on Climate Change (IPCC 2014) in its Fifth Assessment Report (AR5) proposes four Representative Concentration Pathways (RCPs). RCPs may be better than the emission scenarios developed in the Special Report on Emissions Scenarios (SRES); hence, RCPs have replaced SRES standards (Moss et al. 2010). The two pathways (RCP 2.6 and RCP 8.5) represent two possible radiative forcing values $\left(+2.6\right.$ and $+8.5 \mathrm{~W} / \mathrm{m}^{2}$, respectively) (Moss et al. 2010). We used data from 1950-2000 as baseline climate data. Ten GCMs were used for the years 2050s and 2070s. For each GCM, we used the two RCPs to evaluate different greenhouse gas scenarios. Hence, the total number of climate scenarios considered was 40 (10 GCMs, two scenarios and two-time steps).

Ecological niche modeling.-We made a correlative niche model relating environmental conditions to 15 presence records using MaxEnt software (Phillips et al. 2006). We optimized model complexity and predictive power using the R package ENMeval (Muscarella et al. 2014) to select the optimal combination of the regularization multiplier and the combination of feature classes. We tested regularization multiplier values from $0.5-6.0$ with intervals of 0.5 , and evaluated five settings of feature classes, as follow: linear $(\mathrm{L})$; linear and quadratic $(\mathrm{Q})$; hinge $(\mathrm{H})$; $\mathrm{LQH}$; and $\mathrm{LQH}$ plus product $(\mathrm{P})$. The performance of model was evaluated using Akaike Information Criterion corrected for small sample sizes (AICc) (Warren and Seifert 2011). The final model was run in Maxent using 50 bootstrapping replicates and the combination of regularization multiplier and feature classes with lowest AICc using all occurrence records. Additionally, we examined the omission rate and tested AUC to assure that the model selected as optimal performed well.

We used the "minimum training presence" threshold value to discriminate suitable from nonsuitable habitat (Liu et al. 2005, Radosavljevic and Anderson 2014). We used the logistic output of MaxEnt (continuous model), and applied thresholds in ArcGIS to convert it into a presenceabsence model. Then we clipped the binary models by the shape files of natural forests (Estrada et al. 2011) and protected areas (CNAP 2013) to examine the extent of the ecological niche covered by both categories. The ecological niche model generated for A. guamuhaya was 
projected onto two future climate change scenarios and they were added for each RCPs using the median value for all projections-i.e., we used the consensus of only those areas where five or more GCM predict the occurrence of environmentally suitable areas in the future. We subtracted the future and current niche models from each other, and areas of contraction, expansion and stability were calculated.

\section{Reassessment of Conservation Status}

Based on the information available for $A$. guamuhaya, we consider that the most accurate evaluation of its conservation status must follow the IUCN Criterion B-viz., area of occupancy (AOO) and extent of occurrence (EOO) (IUCN 2001, 2012, IUCN Standards and Petitions Subcommittee 2014). We calculated the AOO and the EOO using ArcGIS v. 10.3 (ESRI, Redlands). For the $\mathrm{AOO}$ we used the standardized reference scale grid of $4 \mathrm{~km}^{2}$ cells proposed by the IUCN (IUCN 2001, 2012, IUCN Standards and Petitions Subcommittee 2014). The EOO was estimated with two approaches: (1) the convex hull (e.g., IUCN Standards and Petitions Subcommittee 2014) and (2) the environmentally suitable area resulting from ecological niche modeling clipped by the layer of natural forests. Both approaches are biased toward overestimation. Thus, the convex hull can include several areas of unsuitable habitat (IUCN 2001, 2012, IUCN Standards and Petitions Subcommittee 2014) and ecological niche modeling is unable to detect environmentally suitable areas never occupied by the species (historical biogeography, limited dispersal ability) and the exact areas occupied by ecologically similar species (interference competition). However, ecological niche modeling seems a more realistic measure of habitat suitability; thus, it was used here as the final estimation of EOO. There is also a bias toward underestimation because of the highly irregular topography of the montane region that contains a larger surface area than that of a flat landscape.
Twig-giant anoles are arboreal; therefore, it is reasonable to expect the species to have a strong dependence on forested areas, where canopy connectivity may allow them to disperse. There are no estimates of the average dispersal distance in A. guamuhaya or any other member of the Chamaeleolis clade; nevertheless, using the factors mentioned above, we could qualify the species (and probably most species within this group) as having poor dispersal ability (reviewed in IUCN Standards and Petitions Subcommittee 2014). Therefore, we considered natural forest coverage to be an important variable in estimating habitat decline and EOO. Cuba has a long history of forest depletion resulting from the extensive development of the sugar industry, agriculture, and stockbreeding, which resulted in a reduction of forest coverage of more than $80 \%$ between the $16^{\text {th }}$ century and the mid-20 ${ }^{\text {th }}$ century (Del Risco 1995, GutiérrezDomech and Rivero-Glean 1997). And there are few signs of recovery now (ONEI 2015). We would expect that such an extreme reduction in forest coverage has had long-lasting negative effects on populations of native, forest-dwelling species such as A. guamuhaya. The Guamuhaya Massif is a mountain range where native ecosystems have persisted. However, the primary vegetation has suffered serious impacts from forest fires and intensive felling for coffee plantations and stockbreeding (e.g., DomínguezGonzález and Acosta-Rodríguez 2012, Mancina et al. 2017). Consequently, we consider that the IUCN Criterion $\mathrm{Bb}(\mathrm{iii})$, which refers to continuous decline in the effective area extent and/or quality of habitat, is fully applicable to $A$. guamuhaya.

\section{Results}

\section{Geographic Distribution and Natural History}

With the eight new localities reported here, the current distribution of A. guamuhaya includes nearly the entire Trinidad Range and encompasses 
the three central provinces-Cienfuegos, Villa Clara, and Sancti Spíritus (Figure 1; Appendix I). The three new records from Villa Clara are the first for this province. Two of the new localities are the first lowland records for $A$. guamuhaya, which was found in isolated patches of subcoastal semideciduous forest, about $20 \mathrm{~km}$ west of the nearest previous mountain record at Pico San Juan. The altitudinal distribution is 15$1015 \mathrm{~m}$ a.s.l.

The lowland and montane A. guamuhaya have the same scale pattern described for the holotype. In life, the dorsum of the montane lizards is greenish, whereas that of individuals from the lowlands grayish. The dewlap of montane lizards has more black areas than that of the lowland lizards (Figure 3); however, dewlap coloration can vary. These differences may indicate local adaptations (dry subcoastal vegetation $v s$. mountain rainforest and evergreen forest) and/or genetic drift. The isolated lowland records apparently represent outlying occurrences of the species; these might reflect a reduction in suitable habitat (primary forest) in the transition zone between subcoastal and mountain areas (Ecological Niche Modeling below) and subsequent isolation of the lizards as metapopulations.

We found Anolis guamuhaya mostly associated with primary forest (Figure 4). However, many immature individuals were associated with ecotonal or secondary shrubby vegetation, but these areas always are in direct contact with primary forest (Table 1). The specimens deposited in the collection of the NMP have no ecological data.

Table 1. Summary of ecological data of specimens of Anolis guamuhaya examined in the field. Measurements are presented in centimeters. Juveniles $(\mathrm{J})$ refer to small individuals less than $100 \mathrm{~mm} \mathrm{SVL}$ and adults (A) refer to individuals larger than $100 \mathrm{~mm}$ SVL. Abbreviations: Veg. = vegetation type; SDF = semideciduous forest; $\mathrm{EGF}=$ evergreen forest; $\mathrm{MRF}=$ mountain rainforest; $\mathrm{ECO}=$ ecotonal vegetation; $\mathrm{SEC}=$ secondary vegetation; $\varnothing=$ perch diameter; $\mathrm{SB}=$ shrub branch; $\mathrm{ST}=$ shrub trunk; $\mathrm{TT}=$ tree trunk; $\mathrm{TB}=$ tree branch; $\mathrm{VI}=$ vine.

\begin{tabular}{lllll}
\hline \multirow{2}{*}{ Specimen } & Age & \multicolumn{2}{c}{ Perch } & Observations \\
\cline { 3 - 3 } & & Type $\varnothing \quad$ Height & \\
\hline
\end{tabular}

\section{Cienfuegos}

$\begin{array}{llccccc}\text { MFP 12515 } & \text { J } & \text { SEC } & \text { SB } & 1.1 & 305 & \text { Basking, body temperature } 28^{\circ} \mathrm{C} \text {, air temperature } 27.9^{\circ} \mathrm{C} \\ \text { No voucher } & \text { J } & \text { SEC } & \text { SB } & 1.6 & 240 & \text { Pico San Juan, body temperature } 28^{\circ} \mathrm{C} \text {, air temperature } 27.9^{\circ} \mathrm{C} \\ \text { CZACC 4.5871 } & \text { A } & \text { MRF } & \text { TB } & 1.5 & 400 & \text { Sleeping at night in horizontal position. } \\ \text { MFP 12.633 } & \text { A } & \text { EGF } & \text { SB } & 1.3 & 50 & \text { Swallowing a snail (Zachrysia sp.) } \\ \text { No voucher } & \text { A } & \text { EGF } & \text { ST } & 2.5 & 100 & \text { Carso de Buenos Aires } \\ \text { CZACC 4.5846 } & \text { J } & \text { ECO } & \text { ST } & 2.2 & 110 & \text { On vertical stem, by a trail by day } \\ \text { MFP 12.629 } & \text { A } & \text { SDF } & \text { TT } & 27 & 200 & \text { On smooth palm tree trunk, head down } \\ \text { No voucher } & \text { J } & \text { ECO } & \text { VI } & 0.3 & 120 & \text { Santa Martina, on oblique twig, head up } \\ \text { MFP 12.603 } & \text { A } & \text { SDF } & \text { TB } & 1.8 & 320 & \text { Sleeping at night in vertical position, head up } \\ \text { CZACC } 4.5850 & \text { J } & \text { ECO } & \text { SB } & 0.5 & 50 & \text { Sleeping at night in horizontal position } \\ \text { CZACC } 4.5851 & \text { J } & \text { ECO } & \text { VI } & 0.4 & 200 & \text { Sleeping at night in horizontal position }\end{array}$

Sancti Spíritus

$\begin{array}{llllll}\text { No voucher } & \text { A } & \text { EGF } & \text { VI } & 2 & 200\end{array}$



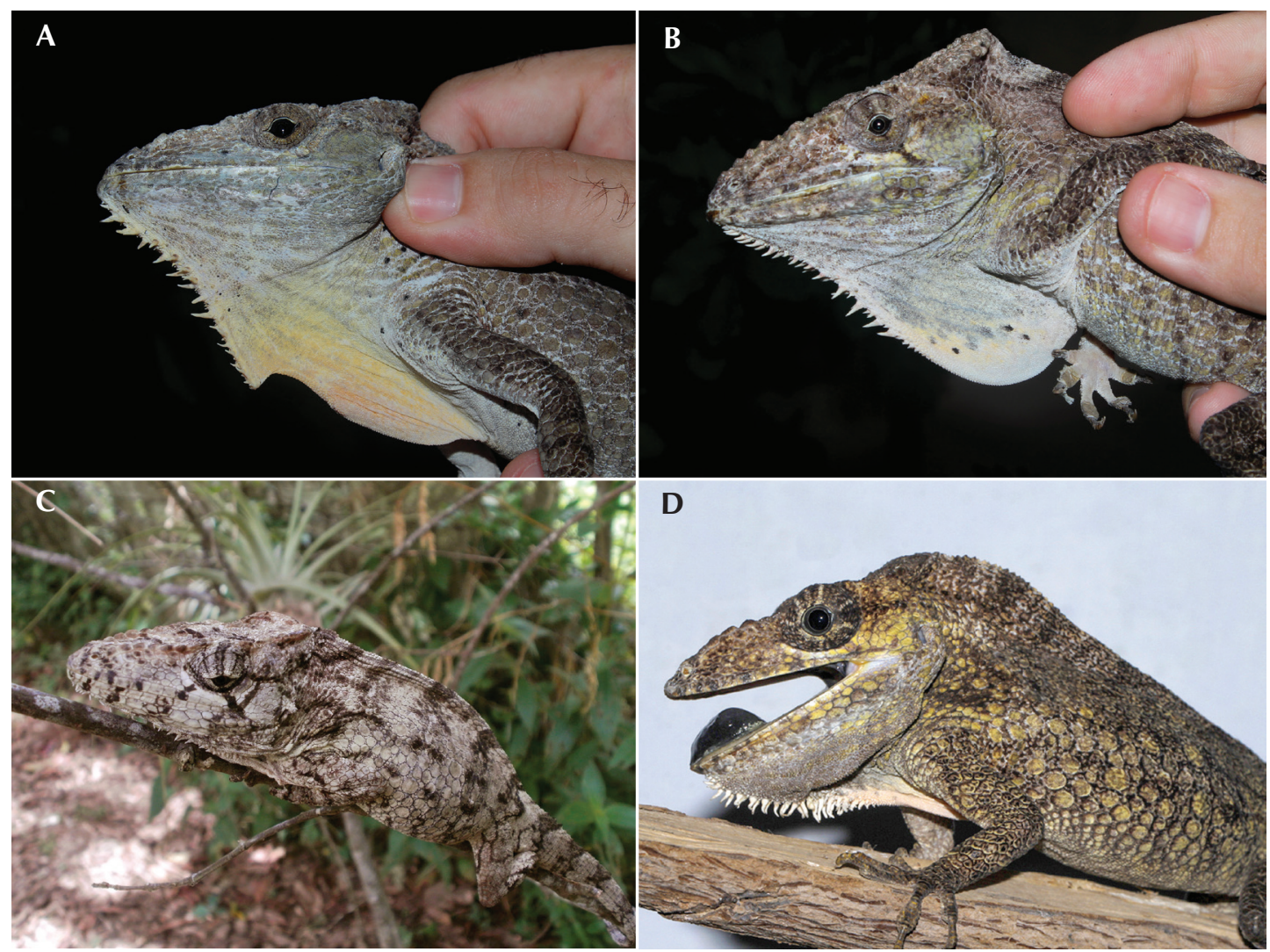

Figure 3. Selection of specimens of Anolis guamuhaya examined for this study: (A) male CZACC 4.5848 from Santa Martina; (B) female CZACC 4.5849 from Boca Ambuila; (C) female CZACC 4.5845 from Carso de Buenos Aires, notice the camouflage; and (D) male from Loma Cariblanca, kept alive at the Parque Zoológico Nacional, La Habana. Photographs by RM (A, B, D) and TMRC (C).

\section{Ecological Niche Modeling}

The ecological niche models for A. guamuhaya have mean values of $\mathrm{AUC}_{\text {training }}=0.938 \pm 0.006$, $\mathrm{AUC}_{\text {test }}=0.940 \pm 0.005$, mean $\mathrm{AUC}_{\text {diff }}=0.025 \pm$ $0.0006 \mathrm{SD}$ and mean of minimum training presence omission rate $=0.227 \pm 0.103 \mathrm{SD}$ (Appendix II). These results indicate good model performance and low overfitting. The lowest values of AICc $(\triangle \mathrm{AICc}=0)$ resulted from regularization multiplier of 1 with linear and quadratic feature classes. The three most important bioclimatic variables are (1) the maximum temperature of the warmest month;
(2) mean diurnal temperature range; and (3) temperature seasonality (Appendix III). The current climatically suitable area encompasses more than $1398 \mathrm{~km}^{2}$ (Figure 5A), but only $46 \%\left(648 \mathrm{~km}^{2}\right)$ is covered by natural forests (Figure $5 \mathrm{~B}$ ).

Under all climate change scenarios, the models predict a reduction of the suitable area; however, the amount of reduction is variable (Figure 6). The models suggest a reduction of suitable areas between 43-67\% in 2050 (Figure 6A, B) and between $44-94 \%$ in 2070 (Figure 6C, D). The largest estimated percent loss in suitable areas occurs under RCP 8.5 scenario for 2070 (Figure 


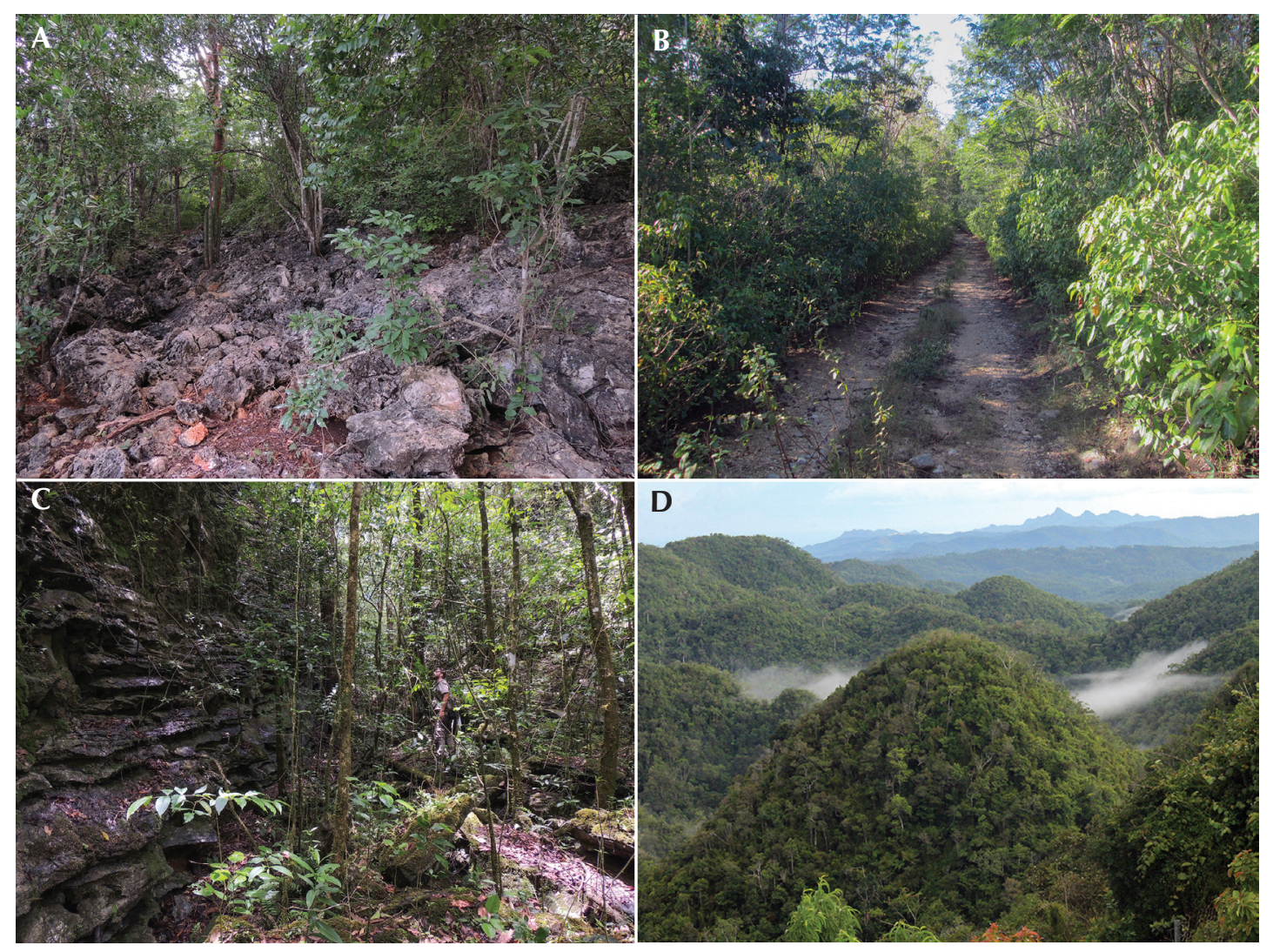

Figure 4. Different habitats of Anolis guamuhaya: (A) subcoastal semideciduous forest on limestone at Boca Ambuila; (B) trail crossing subcoastal semideciduous forest at Santa Martina; (C) evergreen forest on limestone at Carso de Buenos Aires; and (D) mountain rainforest at Pico San Juan. Photographs by TMRC (A-C) and RM (D).

6D) in which only $77 \mathrm{~km}^{2}$ (6\% of the current suitable area) will remain with suitable climatic conditions for the occurrence of A. guamuhaya. However, all these models are clearly overestimated, because they do not include the natural forest coverage, which is expected to be drastically reduced as a collateral effect of climate change.

\section{Conservation Status}

We assigned a grid size of $4 \mathrm{~km}^{2}$ per locality and summarized the 15 records from the literature and this study to estimate the range (AOO) of $A$. guamuhaya at $60 \mathrm{~km}^{2}$. The convex hull revealed an EOO of $622 \mathrm{~km}^{2}$, but the climatically suitable area clipped by the layer of natural forests revealed an EOO of $648 \mathrm{~km}^{2}$, considered herein as the most realistic approach to the EOO(Figure $5 \mathrm{~B})$. We consider that the loss of forest coverage during the last centuries is not only a measure of "continuing decline in area, extend and/or quality of habitat," but also a measure of the extreme decrease in the EOO. Moreover, only 21\% (138 $\mathrm{km}^{2}$ ) of the climatically suitable area covered by natural forests $(=\mathrm{EOO})$ and only seven of the fifteen localities (47\%) of A. guamuhaya fall within protected areas (Figure 5B). 

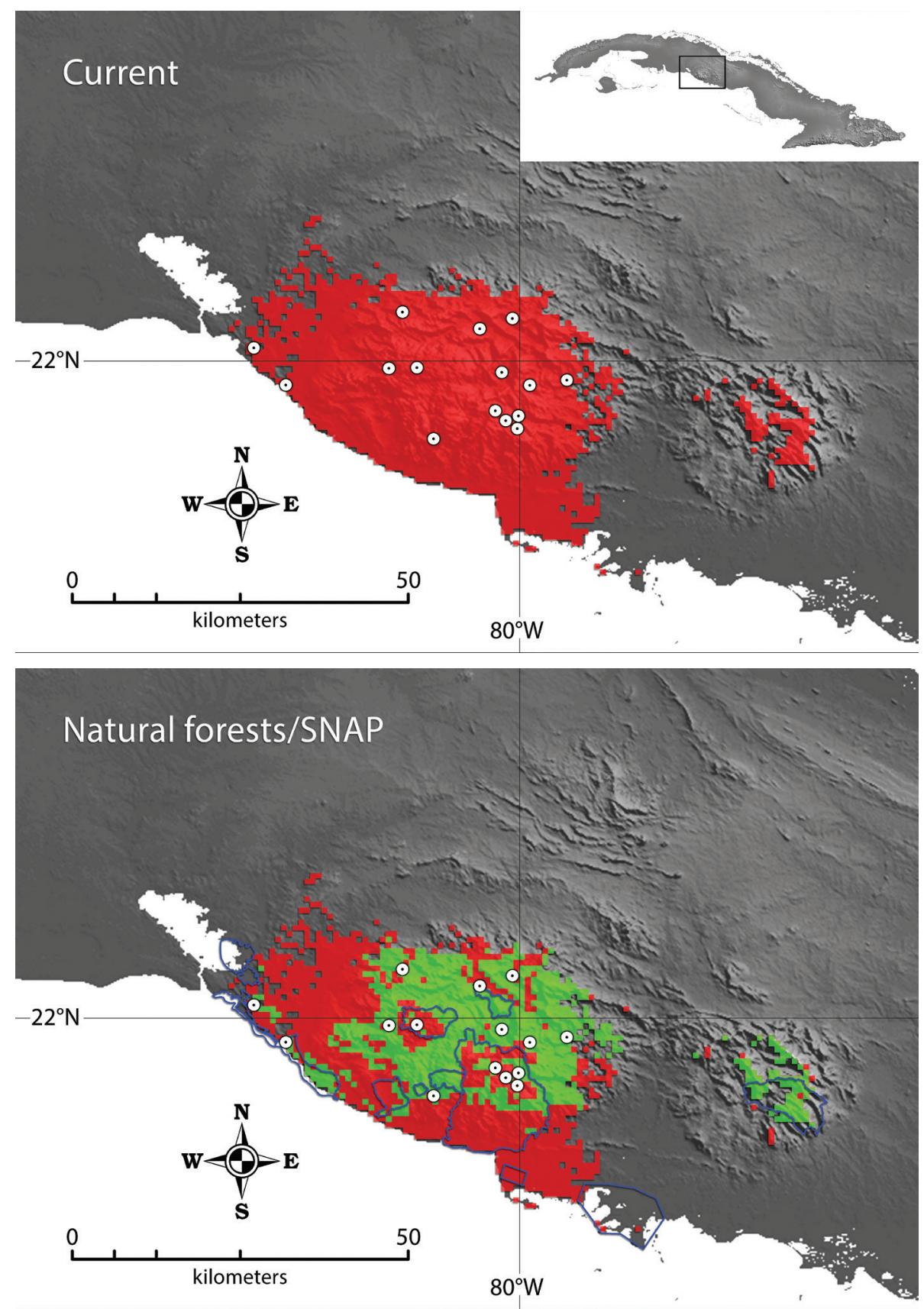

Figure 5. Ecological niche model for Anolis guamuhaya based on presence records (white dots) from the literature and this study. (A) Binary representation of the current environmentally suitable area (red shading) based on the "minimum training presence" threshold (consensus of the scenarios where five or more GCM coincide). (B) Current distribution of environmentally suitable areas clipped by natural forests (green shadings, assumed herein as the EOO) and then by protected areas (blue contours). 

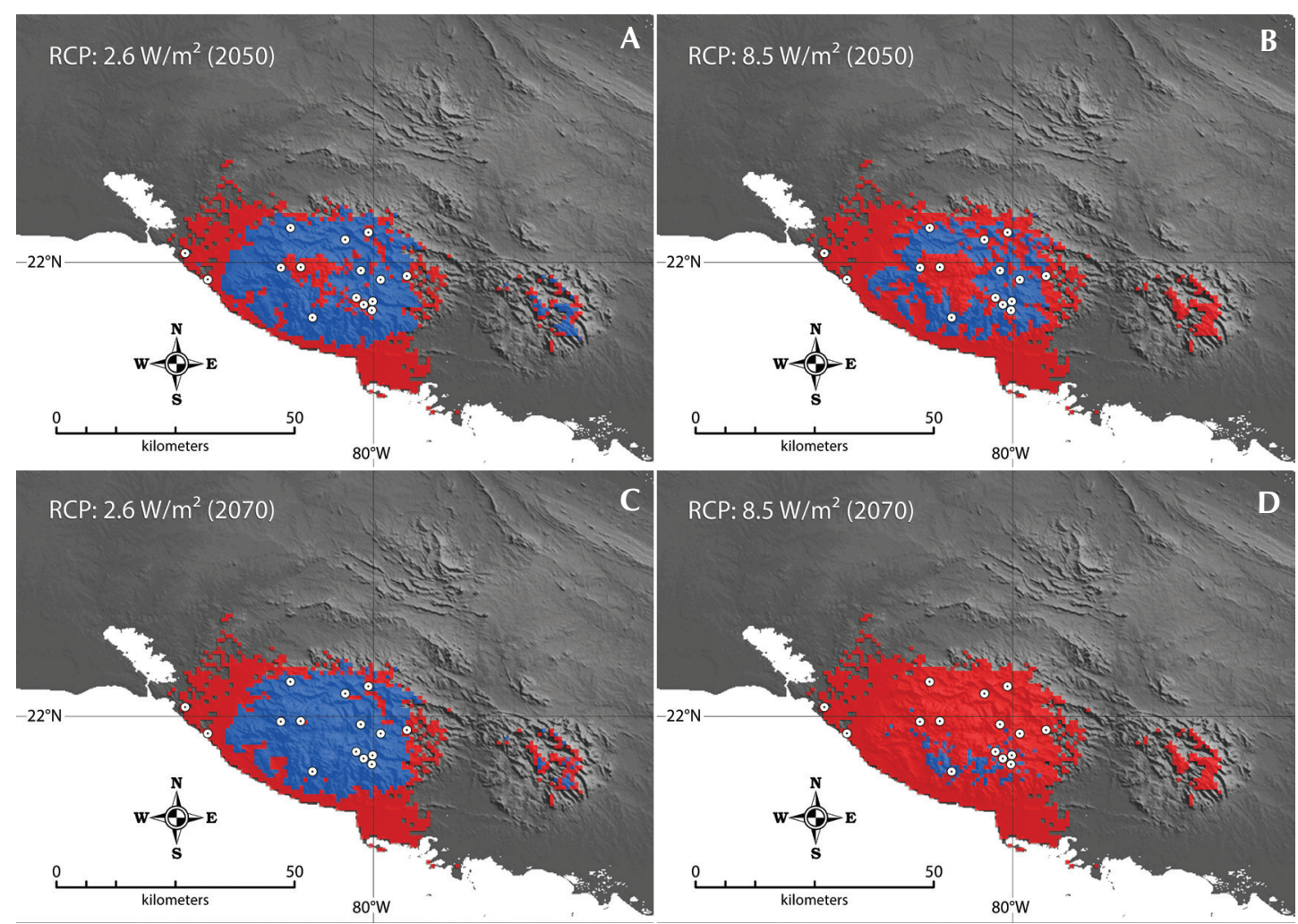

Figure 6. Ecological niche model percent reduction of environmentally suitable areas for Anolis guamuhaya projected under two future climate change scenarios (RCP: $2.6 \mathrm{~W} / \mathrm{m}^{2}$ and $8.5 \mathrm{~W} / \mathrm{m}^{2}$ ) for the years 2050 and 2070 . The blue shading represents the sum of those areas where five or more GCMs predict environmentally suitable conditions. The red shading represents the current environmentally suitable areas, illustrating retraction under future scenarios; no expansion was observed under any scenario.

\section{Discussion}

Most authors have reported A. guamuhaya to occur above $300 \mathrm{~m}$ a.s.l. (Garrido et al. 1991, Rodríguez 2012, Rodríguez et al. 2010, 2013); Henderson and Powell (2009) reported an elevational distribution for this species from sea level to $900 \mathrm{~m}$, although no voucher specimens from lowland localities are mentioned. The specimens reported here from the southern coast of Cienfuegos Province are the first vouchered records of this species in lowland ecosystems.
The greater number of voucher specimens from a cluster of localities in the vicinity of Topes de Collantes does not necessarily imply higher population density. It is more likely that it reflects a greater sampling effort because this area attracts many tourists, as well as researchers.

As observed here and reported in the literature, A. guamuhaya is both a mountain- and lowland-dwelling species, ranging from close to the sea level to above $1000 \mathrm{~m}$. However, environmentally suitable areas and primary forest coverage in south-central Cuba are scarce and highly fragmented apart from the Guamuhaya 
Massif (Figures 5 and 7). Montane ecosystems are the last natural refuge for this species under the worst-case scenarios of climate change in the future (Figure 6).

Climate change and the modification and fragmentation of natural forests seem to challenge the survival of $A$. guamuhaya. Changes in range size usually are assessed by considering the climatic characteristics of current distributions and the projected distribution of these climatic conditions in the future. However, the vulnerability of this lizard may be exacerbated by other factors. These anoles seem to have a limited dispersal ability; further, they are affected by the loss and fragmentation of forest patches within climatically suitable areas, because forest coverage/canopy connectivity may affect the conditions (microclimate) and resources (habitat structure) required by the species.

The model identified environmentally suitable areas for A. guamuhaya only in the Guamuhaya Massif and its nearby surroundings, including in the Sancti Spíritus Range, about $30 \mathrm{~km}$ east of the nearest records of the species (Figure 5). However, despite extensive surveys through the years, the only twig-giant anole that has been found so far in the latter area is A. chamaeleonides Duméril and Bibron, 1837, which also occurs in the southeastern portion of the Trinidad Range, close to $A$. guamuhaya (Figure 7; Garrido et al. 1991, Estrada 1994, Rodríguez et al. 2013, authors pers. obs.). All species in the Chamaeleolis clade apparently have similar ecological requirements, and sympatry rarely has been reported (e.g., Rodríguez

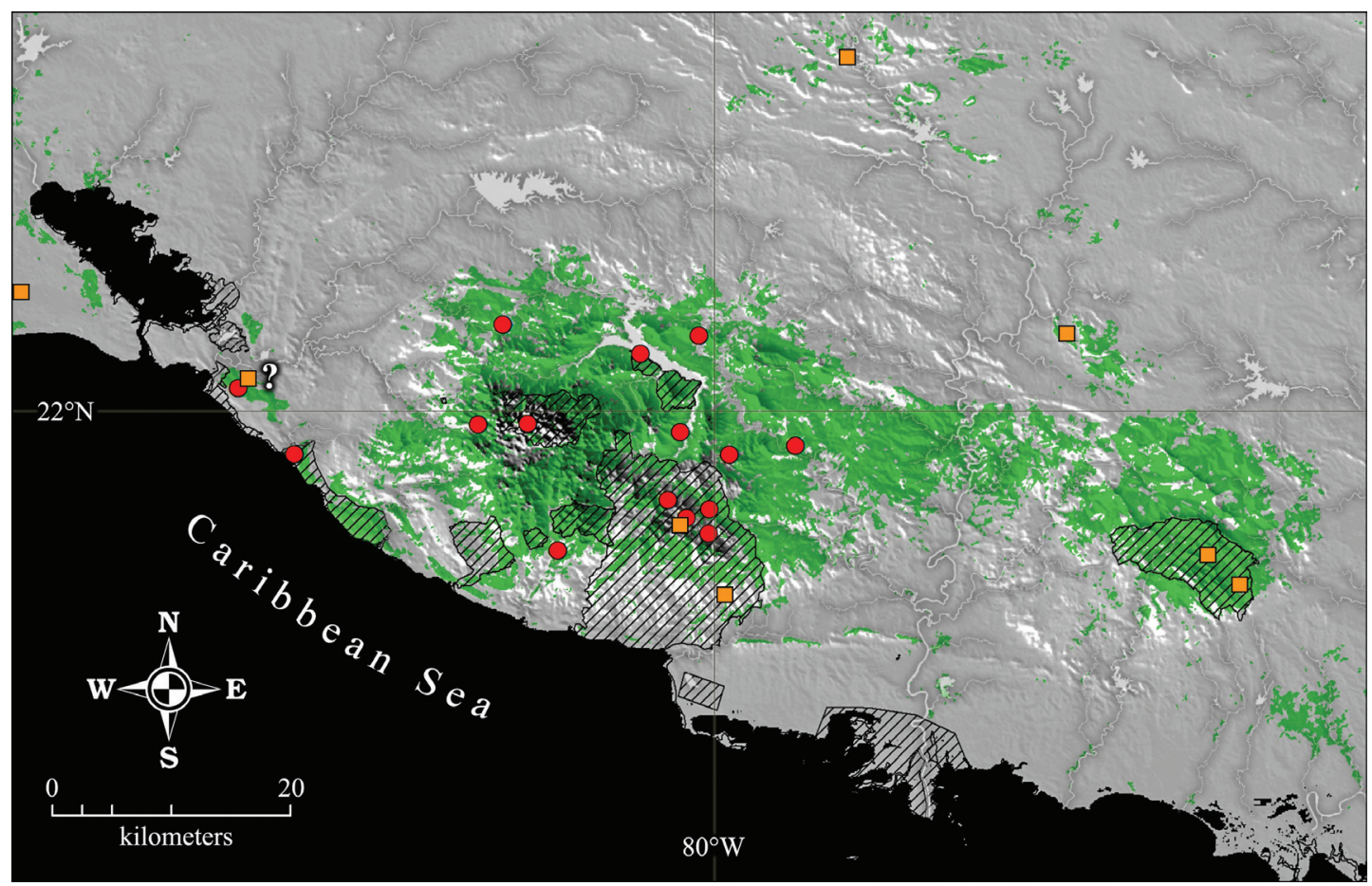

Figure 7. Records of Anolis guamuhaya (red dots) and A. chamaeleonides (orange squares) in south-central Cuba (sensu Rodríguez et al. 2013 and this study), superimposed to the layer of current natural forests (green shading) and protected areas (striped zones). Question mark represents the juvenile male CZACC 4.5846 from Santa Martina, tentatively assigned to $A$. chamaeleonides. 
et al. 2013), which might be indicative of competitive exclusion (Morin 2011). Higher resource requirements in giant anoles may indicate a stronger interference competition among ecologically similar species. For example, $A$. guamuhaya and A. chamaeleonides apparently occur sympatrically at Topes de Collantes (Rodríguez et al. 2013) but the overlap in distribution seems to be minimal (Figure 7). Because no ecological studies exist on interspecific interactions between these species, this scenario provides a unique opportunity to study resource partitioning between twig-giant anoles.

We found one juvenile specimen at Santa Martina (CZACC 4.5846) that we tentatively assigned to A. chamaeleonides (because it had a scale row between the supralabials and infraoculars; Garrido et al. 1991), but its small size made it difficult to identify unambiguously (Figure 8; Appendix I). Thus, a second probable point of contact between A. guamuhaya and A. chamaeleonides might be Santa Martina. This seems plausible because the latter species is known to occur in similar ecological conditions about $20 \mathrm{~km}$ northwestward, near Juraguá, on the western side of Cienfuegos Bay (Figure 8; Garrido 1980, Rodríguez et al. 2013). Anolis chamaeleonides is widespread in Cuba (Rodríguez et al. 2013), from sea level to above $1000 \mathrm{~m}$ (Rodríguez et al. 2010), which suggests that it is more generalist than A. guamuhaya. Therefore, its absence throughout most of the range of A. guamuhaya in the Trinidad Range supports the hypothesis of strong competition between both species.

This is an example of the importance of ground-truthing to assess the incidence of biotic interactions (e.g., competition, predators, food availability) and abiotic factors (e.g., geographic and ecological barriers) in species distributions when using ecological niche modeling (Soberón and Nakamura 2009). The climatically suitable areas generated by the models do not necessarily represent the full distribution of the species. Given the apparently low dispersal ability of $A$. guamuhaya and strong barrier imposed by the

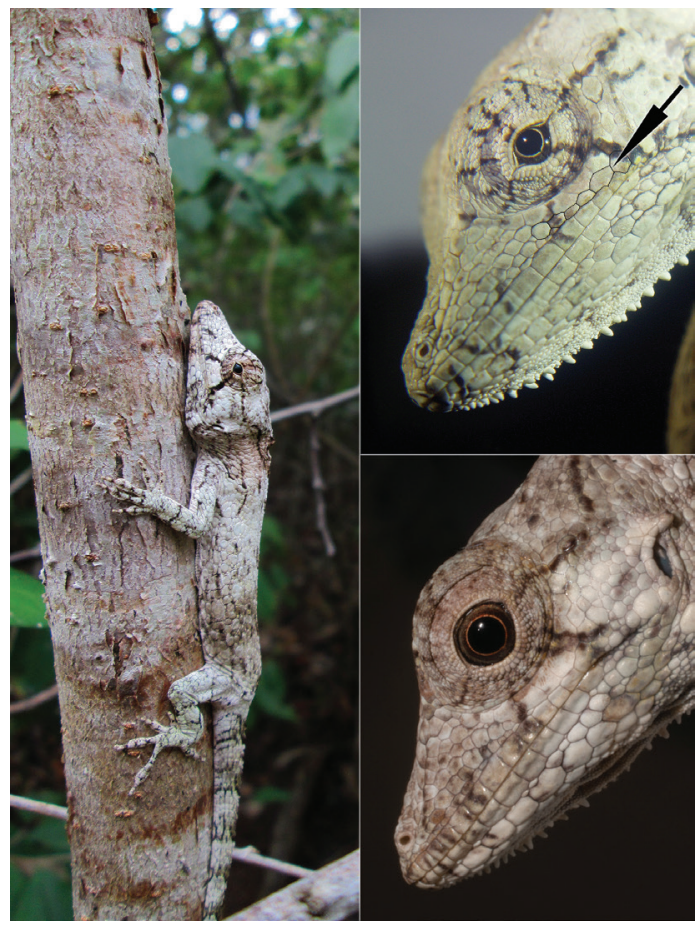

Figure 8. Juvenile male CZACC 4.5846 (52.2 mm SVL) from Santa Martina, tentatively assigned to Anolis chamaeleonides. The inset above shows details of the scale row between supralabials and infraoculars (arrow, also the scale row in was outlined to increase legibility), which is a diagnostic character for this species. The inset below shows details of the head of a juvenile male $A$. guamuhaya of comparable size (57 $\mathrm{mm}$ SVL) from the southwestern slope of Pico San Juan, notice the supralabials in contact with the infraoculars. Photographs by TMRC.

Agabama Basin, it is possible that this species never dispersed into the Sancti Spíritus Range, despite the occurrence of climatically suitable habitats in these mountains. Another possibility is that A. chamaeleonides has been progressively displacing A. guamuhaya from east to west. The severe deforestation of the Sancti Spíritus Range in the past (e.g., Domínguez-González and Acosta-Rodríguez 2012, Mancina et al. 2017) 
translates to strong habitat modifications that might have produced the retreat of $A$. guamuhaya and favored the advance of $A$. chamaeleonides. This hypothesis could be tested by using molecular markers to assess if the populations of A. chamaelonides found in the Sancti Spiritus range came from nearby eastern populations.

Another factor that may affect A. guamuhaya and potentially limit its distribution is competition with ecologically similar species such as $A$. chamaeleonides. The latter species seems more adaptable; thus, under future scenarios of climate change and overall loss/modification of suitable habitats it could displace A. guamuhaya. Although both forest coverage and interference competition have the potential to affect the distribution of A. guamuhaya significantly, they cannot be modelled predictably with current tools.

If we assume that the climatically suitable areas generated by the ecological niche model are a measure of the species range, then the $\mathrm{EOO}$, the number of locations, and its $\mathrm{AOO}$ decrease under all future scenarios of climate change. Given these changes, the status of $A$. guamuhaya would fulfill the IUCN criteria in the category of Endangered (B1ab[i,ii,iii,iv], c[i]; B2ab[i,ii,iii,iv], c[i]). Nonetheless, this estimated EOO of A. guamuhaya is just a first approach to the reality because of the difficulty in determining the exact area occupied by a species on a highly irregular topography such as that of the Guamuhaya Massif. Moreover, part of this EOO is occupied by a closely related and ecologically similar species (A. chamaeleonides) that apparently can replace $A$. guamuhaya and further reduce its effective EOO (Figure 7; see below). However, the exact area occupied by $A$. chamaeleonides and the degree to which it reduces the effective EOO of A. guamuhaya is difficult to estimate.

Anolis guamuhaya remains in the Endangered category, as previously evaluated by other authors following the IUCN Criterion D (Rodríguez 1999, 2012). However, we consider that IUCN Criterion B is more plausible for twig-giant anoles because it allows a more realistic assessment. The ecological niche models that we obtained for A. guamuhaya predict that under future scenarios of climate change, the environmentally suitable area for this species reaches a critical value under scenario RCP 8.5 $\mathrm{W} / \mathrm{m}^{2}$ for 2070 , in which only $77 \mathrm{~km}^{2}$ of the Guamuhaya Mountains would remain compatible with the species requirements. Moreover, it is reasonable to associate this reduction in climatically suitable habitat with a severe decline in natural forest coverage. For this reason, we consider that A. guamuhaya may fulfill the IUCN criteria for the Critically Endangered category in 2070. This situation would be exacerbated if, in fact, the species currently does not occupy all its potential distribution because of other factors apart from climatic suitability, such as forest coverage reduction and interference competition.

The fact that we found several specimens of A. guamuhaya in secondary vegetation suggests that the species can survive some degree of habitat deterioration. However, all the places where we found the species in secondary vegetation were ecotonal areas at the edge of larger patches of primary vegetation (semideciduous forest or mountain rainforest) having different degrees of canopy connectivity. These individuals inhabiting ecotonal areas may be incipient dispersers, with their presence not necessarily evidencing ecological success in deteriorated habitats. Indeed, all individuals we found in ecotonal secondary vegetation were juveniles; these lizards may be density-dependent emigrants that are dispersing in response to inbreeding and/or kin competition (Begon et al. 2006). In fact, we never found adult $A$. guamuhaya in isolated patches of secondary vegetation; this would seem to suggest that the species is unable to survive after a relatively low level of habitat deterioration.

More extensive, long-term studies on the demographic parameters and ecological requirements of $A$. guamuhaya are needed to assess its conservation status accurately. This is 
particularly important because more than a half $(53 \%)$ of all records of the species are outside the network of protected areas in Cuba. This consideration should be a matter of utmost concern when environmental authorities formulate action plans and conservation strategies.

\section{Acknowledgments}

We thank Julio León, Raimundo LópezSilvero, Alejandro M. Rodríguez, Paidel Gutiérrez, and Lázaro Fernández for field assistance. Alexander Arango kindly allowed us to take photographs and provided measurements of the specimen under his care at the Parque Zoológico Nacional, La Habana, Cuba. We also thank Luis F. de Armas for providing useful information regarding the exact locality of the paratype CZACC 4.1549 collected by him in 1978 and to Orlando H. Garrido for granting us an interview regarding the holotype of $A$. guamuhaya. Manuel Iturriaga and Adonis González provided access to the specimens deposited in the Instituto de Ecología y Sistemática, and Alejandro Barro and Roberto Alonso to the specimens deposited in the Museo de Historia Natural "Felipe Poey" of the Universidad de La Habana. Alejandro Palmarola provided literature references. The management of the Cienfuegos Botanical Garden and the meteorological radar station at Pico San Juan (Guamuhaya) provided logistical support during field expeditions. The Earthwatch Institute, the Wildlife Conservation Society (WCS), and the Sociedad Cubana de Zoología provided financial and technical support during expeditions made to the "Lomas de Banao" Ecological Reserve, Sancti Spiritus range, particularly to Maikel Cañizares, Lucía Hechevarría, and Natalia Rossi (WCS) who arranged the expeditions, the many volunteers that assisted us in the field and the staff from the "Lomas de Banao" Ecological Reserve for providing us with excellent treatment and accommodations. This work is also part of the results of the project "Explorando los Efectos del Cambio Climático sobre la Biota Cubana," Programa Nacional de Cambio Climático (CITMA). Finally, Sheila Rodríguez, Marlon E. Cobos and Linda Trueb made useful comments that improved the manuscript.

\section{References}

Anderson, R. P. 2013. A framework for using niche models to estimate impacts of climate change on species distributions. Annals of the New York Academy of Sciences 1297: 8-28.

Anderson, R. P. and A. Raza. 2010. The effect of the extent of the study region on GIS models of species geographic distributions and estimates of niche evolution: preliminary tests with montane rodents (genus Nephelomys) in Venezuela. Journal of Biogeography 37: 1378-1393.

Barve, N., V. Barve, A. Jiménez-Valverde, A. Lira-Noriega, S. P. Maher, A. T. Peterson, J. Soberón, and F. Villalobos. 2011. The crucial role of the accessible area in ecological niche modeling and species distribution modeling. Ecological Modeling 222: 1810-1819.

Begon, M., C. R. Townsend, and J. L. Harper. 2006. Ecology. From Individuals to Ecosystems. $4^{\text {th }}$ Edition. Malden. Blackwell Publishing. 738 pp.

CNAP (Centro Nacional de Áreas Protegidas). 2013. Plan del Sistema Nacional de Áreas Protegidas 2014-2020. La Habana. Ministerio de Ciencias, Tecnología y Medio Ambiente. 366 pp.

Del Risco, E. 1995. Los Bosques de Cuba: Su Historia y Características. La Habana. Editorial CientíficoTécnica. 94 pp.

Díaz, L. M., N. Navarro, and O. H. Garrido. 1998. Nueva especie de Chamaeleolis (Sauria: Iguanidae) de la Meseta de Cabo Cruz, Granma, Cuba. Avicennia 8/9: 27-34.

Domínguez-González, A. Z. and E. Acosta-Rodríguez. 2012. Características ambientales de la provincia de Sancti Spíritus. Chapter I. Pp. 1-43 in A. Z. Domínguez González, M. Torres Martínez, and Y. G. Puerta de Armas (eds.), Experiencias en la Protección de la Biodiversidad y el Desarrollo Sostenible en la Provincia de Sancti Spíritus. La Habana. Ministerio de Ciencia, Tecnología y Medio Ambiente.

Estrada, A. R. 1994. Herpetofauna de la Cuenca BanaoHiguanojo, Sancti Spíritus, Cuba. Revista de la Academia Colombiana de Ciencias 19: 353-360. 
Estrada, R., G. Martín, P. Martínez, S. Vioel, R. Capote, I. Reyes, S. Galano, C. Cabrera, C. Martínez, L. Mateo, Y. Guerra, A. Batte, and L. Coya. 2011. Mapa (BD-SIG) de vegetación natural y seminatural de Cuba v.1 sobre Landsat etm 7 slc-off gap filled, circa 2011. Memorias del IV Congreso de Manejo de Ecosistemas y Biodiversidad, ISBN 978-959-300-034-5. La Habana, Cuba.

Garrido, O. H. 1980. Los vertebrados terrestres de la Península de Zapata. Poeyana 203: 1-49.

Garrido, O. H. 1982. Descripción de una nueva especie de Chamaeleolis (Lacertilia: Iguanidae), con notas sobre su comportamiento. Poeyana 236: 1-25.

Garrido, O. H. and A. Schwartz. 1968. Cuban lizards of the genus Chamaeleolis. Quarterly Journal of the Florida Academy of Sciences 30: 197-220.

Garrido, O. H., O. Pérez Beato, and L. V. Moreno. 1991. Nueva especie de Chamaeleolis (Lacertilia: Iguanidae) para Cuba. Caribbean Journal of Science 17: 162-168.

Gutiérrez-Domech, R. and M. Rivero-Glean. 1997. Minigeografía de Cuba. La Habana. Editorial CientíficoTécnica. 142 pp.

Hass, C. A., S. B. Hedges, and L. R. Maxson. 1993. Molecular insights into the relationships and biogeography of West Indian anoline lizards. Biochemical Systematics and Ecology 21: 97-114.

Henderson, R. W. and R. Powell. 2009. Natural History of West Indian Amphibians and Reptiles. Gainesville. University Press of Florida. 513 pp.

Herrel, A. and V. Holanova [Holáňová Zahradníčková]. 2008. Cranial morphology and bite force in Chamaeleolis lizards. Adaptations to molluscivory? Zoology 111: 467-475.

Hijmans, R. J., S. E. Cameron, J. L. Parra, P. G. Jones, and A. Jarvis. 2005. Very high resolution interpolated climate surfaces for global land areas. International Journal of Climatology 25: 1965-1978.

Holáňová Zahradníčková, V., A. Abramjan, K. Palupčíková, I. Rehák, and D. Frynta. 2017. Discovering an Antillean Anolis (Squamata: Polychrotidae) with contrasting sexual dichromatism in otherwise sexually monomorphic "chamaeleolis" group. Acta Societatis Zoologicae Bohemoslovenicae 81: 31-47.

IPCC (Intergovernmental Panel on Climate Change). 2014. Climate Change 2014: Synthesis Report. Contribution of Working Groups I, II and III to the Fifth Assessment Report of the Intergovernmental Panel on Climate Change. R. K Pachauri and L. A. Mayer (eds.). Geneva. Intergovernmental Panel on Climate Change. 151 pp.
ITZN (International Trust for Zoological Nomenclature). 1999. International Code of Zoological Nomenclature. $4^{\text {th }}$ Edition. London. International Trust for Zoological Nomenclature. $106 \mathrm{pp}$.

IUCN. 2001. IUCN Red List Categories and Criteria: Version 3.1. Gland and Cambridge. IUCN Species Survival Commission. 33 pp.

IUCN. 2012. IUCN Red List Categories and Criteria. Version 3.1. $2^{\text {nd }}$ Edition. Eletronic Database accessible at http: // www.iucnredlist.org/technical-documents/categoriesand-criteria. Captured on 15 March 2018.

IUCN Standards and Petitions Subcommittee. 2014. Guidelines for Using the IUCN Red List Categories and Criteria. Version 11. Eletronic Database accessible at http: //www.iucnredlist.org/documents/RedListGuideli nes.pdf. Captured on 15 March 2018.

Jackman, T. R., A. Larson, K. de Queiroz, and J. B. Losos. 1999. Phylogenetic relationships and tempo of early diversification of Anolis lizards. Systematic Biology 48: $254-285$.

Leal, M. and J. B. Losos. 2000. Behavior and ecology of the Cuban "chipojos bobos" Chamaeleolis barbatus and $C$. porcus. Journal of Herpetology 34: 318-322.

Liu, C., P. M. Berry, T. P. Dawson, and R. G. Pearson. 2005. Selecting threshold of occurrence in the prediction of species distributions. Ecography 28: 385-393.

Mancina, C. A. and D. D. Cruz Flores (eds.). 2017. Diversidad Biológica de Cuba: Métodos de Inventario, Monitoreo y Colecciones Biológicas. La Habana. Editorial AMA. 502 pp.

Mancina, C. A., R. Fernández de Arcila Fernández, D. D. Cruz Flores, M. A. Castañeira Colomé, and A. GonzálezRosell. 2017. Diversidad biológica terrestre de Cuba. Pp. 8-25 in C. A. Mancina and D. D. Cruz (eds.), Diversidad Biológica de Cuba: Métodos de Inventario, Monitoreo y Colecciones Biológicas. La Habana. Editorial AMA.

Mateo-Rodríguez, J. and M. Acevedo-González. 1989. Regionalización físico-geográfica 5. 1: 3000 000. Pp XII.2.1 in G. Oliva (ed.), Nuevo Atlas Nacional de Cuba. Academia de Ciencias de Cuba and Instituto Cubano de Geodesia y Cartografía. Instituto de Geografía Nacional de España.

Morin, P. J. 2011. Community Ecology. $2^{\text {nd }}$ Edition. Oxford. Blackwell Publishing. 407 pp.

Moss, R. H., J. A. Edmonds, K. A. Hibbard, M. R. Manning, S. K. Rose, D. P. van Vuuren, T. R. Carter, S. Emori, M. Kainuma, T. Kram, G. A. Meehl, J. F. B. Mitchell, N. Nakicenovic, K. Riahi, S. J. Smith, R. J. Stouffer, A. M. Thomson, J. P. Weyant, and T. J. Wilbanks. 2010. The next generation of scenarios for climate change research and assessment. Nature 463: 747-756. 
Muscarella, R., P. J. Galante, M. Soley, R. Boris, J. Kass, M. Iriarte, and R. P. Anderson. 2014. ENMeval: an R package for conducting spatially independent evaluations and estimating optimal model complexity for Maxent ecological niche models. Methods in Ecology and Evolution 5: 1198-1205.

ONEI (Oficina Nacional de Estadística e Información). 2015. Anuario Estadístico de Cuba, 2014. Eletronic Database accessible at http: //www.one.cu. Captured on 14 Mayo 2017.

Peterson, A. T., J. Soberón, R. G. Pearson, R. P. Anderson, E. Martínez-Meyer, M. Nakamura, and M. B. Araújo. 2011. Ecological Niches and Geographic Distributions. Monographs in Population Biology 49. Princeton. Princeton University Press. 314 pp.

Phillips, S. J. and M. Dudik. 2008. Modeling of species distributions with Maxent: new extensions and a comprehensive evaluation. Ecography 31: 161-175.

Phillips, S. J., R. P. Anderson, and R. E. Schapire. 2006. Maximum entropy modeling of species geographic distributions. Ecological Modeling 190: 231-259.

Poe, S. 2013. 1986 Redux: new genera of anoles (Squamata: Dactyloidae) are unwarranted. Zootaxa 3626: 295-299.

Poe, S., A. Nieto-Montes de Oca, O. Torres-Carvajal, K. De Queiroz, J. A. Velasco, B. Truett, L. N. Gray, M. J. Ryan, G. Köhler, F. Ayala-Varela, and I. Latella. 2017. A phylogenetic, biogeographic, and taxonomic study of all extant species of Anolis (Squamata; Iguanidae). Systematic Biology 66: 663-697.

Pyron, R. A., F. T. Burbrink, and J. J. Wiens. 2013. A phylogeny and revised classification of Squamata, including 4161 species of lizards and snakes. BMC Evolutionary Biology 13: 93-146.
Radosavljevic, A. and R. P. Anderson. 2014. Making better MAXENT models of species distributions: complexity, overfitting and evaluation. Journal of Biogeography 41: 629-643.

Rodríguez Schettino, L. 1999. Systematic accounts of the species. Pp. 104-380 in L. Rodríguez Schettino (ed.), The Iguanid Lizards of Cuba. Gainesville. University Press of Florida.

Rodríguez Schettino, L. 2012. Chamaeleolis guamuhaya. Pp. 141-142 in H. González Alonso, L. Rodríguez Schettino, C. A. Mancina, and I. Ramos-García (eds.), Libro Rojo de los Vertebrados de Cuba. La Habana. Editorial Academia.

Rodríguez Schettino, L., C. A. Mancina, and V. RivaltaGonzález. 2013. Reptiles of Cuba: checklist and geographic distribution. Smithsonian Herpetological Information Service 144: 1-96.

Rodríguez Schettino, L., V. Rivalta-González, and E. PérezRodríguez. 2010. Distribución regional y altitudinal de los reptiles de Cuba. Poeyana 498: 11-20.

Soberón, J. and M. Nakamura. 2009. Niches and distributional areas: concepts, methods, and assumptions. Proceedings of the National Academy of Sciences 17: 19644-19650.

Torres, J., R. Marrero, and T. M. Rodríguez-Cabrera. 2015. Anolis guamuhaya (Escambray Bearded Anole). Maximum Elevation. Herpetological Review 46: 86-87.

Warren, D. L. and S. N. Seifert. 2011. Ecological niche modeling in Maxent: the importance of model complexity and the performance of model selection criteria. Ecological Applications 21: 335-342.

Wilson, E. O. 1957. Behavior of the Cuban lizard Chamaeleolis chamaeleontides (Duméril and Bibron) in captivity. Copeia 1957: 145. 
Rodríguez-Cabrera et al.

Appendix I. Material examined and update of localities with coordinates and elevations reported for Anolis guamuhaya and A. $c f$. chamaeleonides used in this study, from the literature and this paper

$(\mathrm{N}=32$ records, 15 locations). An asterisk (*) represents voucher declared in this paper.

Acronyms and abbreviations declared in Materials and Methods.

\begin{abstract}
Anolis guamuhaya
Type locality: the road between Jibacoa [22.01699, -79.98912; $330 \mathrm{~m}$ a.s.1.], Villa Clara province, and Topes de Collantes [21.9186, -80.02060; $700 \mathrm{~m}$ a.s.1.], Sancti Spíritus province, including elevations of $800 \mathrm{~m}$ [female MNHNCu-500, holotype] (Garrido et al. 1991).

CIENFUEGOS province: Cumanayagua municipality: — Mina Carlota (22.07171, -80.17762; 300-600 m a.s.1.) (male MCZ R-53598, dry skeleton) (Wilson 1957, Garrido and Schwartz 1968, Garrido et al. 1991); — southwestern slope of Pico San Juan (21.98990, -80.14939; 1,015 m a.s.1.) [juvenile male MFP 12515 (Torres et al. 2015); juvenile male, no voucher (57 mm SVL), 8.x.2013; female CZACC 4.5871* (162 mm SVL, $121 \mathrm{~mm}$ TL), 25.viii.2014], collected/examined by T. M. Rodríguez-Cabrera, R. Marrero, J. Torres, P. Gutiérrez-Macías, and A. M. Rodríguez; — ca. 6 km SW of Aguacate $(21.88775,-80.12651 ; 350 \mathrm{~m}$ a.s.1.) [female CZACC 4.1549; formerly IZ-5397 (Garrido 1982) and CZACC:7499 (Garrido et al. 1991)]; — Carso de Buenos Aires (21.98872, -80.18981; $760 \mathrm{~m}$ a.s.1.) [female MFP 12.633* (146 mm SVL, $123 \mathrm{~mm}$ TL, $39 \mathrm{~g}$ ), 19.vii.2014; adult, no voucher, 21.ii.2015], collected/examined by T. M. Rodríguez-Cabrera and J. León; — near the Trinitario stream waterfall (22.00705, -80.04250; $550 \mathrm{~m}$ a.s.1.) (adult, no voucher), examined by E. Morell; — Santa Martina (22.01833, -80.38369; $40 \mathrm{~m}$ a.s.1.) [male MFP 12.629* (165 mm SVL, $203 \mathrm{~mm}$ TL, 87.2 g), 27.viii.2014; juvenile male, no voucher (49 mm SVL, $48 \mathrm{~mm}$ TL)], collected/examined by T. M. Rodríguez-Cabrera, J. Torres, P. Gutiérrez-Macías, A. M. Rodríguez, and L. Fernández; - Boca Ambuila, eastward of the Gavilanes river mouth (21.96478, -80.33822; $15 \mathrm{~m}$ a.s.1.) [female MFP 12.603* (175 mm SVL, $167 \mathrm{~mm}$ TL, $80 \mathrm{~g}$ ); juvenile female CZACC 4.5850* (64 mm SVL, $57 \mathrm{~mm}$ TL, $4.5 \mathrm{~g}$ ); juvenile female CZACC 4.5851* (59 mm SVL, 41 mm TL, 4 g)], 24.ix.2014, collected by T. M. Rodríguez-Cabrera, R. López-Silvero, and R. Domínguez. VILLA CLARA province: Manicaragua municipality: — near the Río Negro Touristic Center (22.04567, -80.05894; $400 \mathrm{~m}$ a.s.1.) (adult, no voucher), examined by E. Morell; — southeastern slope of Loma Cariblanca (22.06025, -80.01181; $400 \mathrm{~m}$ a.s.1.) [male (140 mm SVL, $130 \mathrm{~mm}$ TL, $47.5 \mathrm{~g}$ ), currently kept alive at the Parque Zoológico Nacional, La Habana, Cuba], collected by E. Morell. SANCTI SPÍRITUS province: Trinidad municipality: — Topes de Collantes (21.91194, -80.02000; $700 \mathrm{~m}$ a.s.1.) and vicinity, within a radius of $1 \mathrm{~km}$ (650-800 m a.s.1.) (USNM-156786, male NMP6V 34517, female NMP6V 71870/1, male NMP6V 71870/2, male NMP6V 71870/3, female NMP6V 71870/4, male NMP6V 71870/5, male NMP6V 71870/6, male NMP6V 71870/7, female CZACC 4.5506) (Garrido and Schwartz 1968, Garrido 1982, Rodríguez et al. 2013, Holáňová et al. 2017) — La Chispa (21.92246, -80.03304; $800 \mathrm{~m}$ a.s.1.) (no voucher) (Garrido et al. 1991); — Caburní waterfall (21.92076, -80.00363; 400 m a.s.1.) (no voucher) (Rodríguez et al. 2013); — ca. 2 km southeast of Topes de Collantes, near Vegas Grandes village (21.90250, -80.00500; $650 \mathrm{~m}$ a.s.1.) (male NMP6V 71870/8*, male NMP6V 71871*); — near the resurgence of the Jibacoa river (21.97158, -79.93372; $200 \mathrm{~m}$ a.s.1.) (adult, no voucher), examined by T. M. Rodríguez-Cabrera.
\end{abstract}

Anolis cf. chamaeleonides.

CIENFUEGOS province: Cumanayagua municipality: Santa Martina (22.01833, -80.38369; $40 \mathrm{~m}$ a.s.1.) [juvenile male CZACC 4.5846* (52.2 mm SVL, $50 \mathrm{~mm}$ TL), 22.ii.2014], collected/examined by T. M. Rodríguez-Cabrera, J. Torres, P. Gutiérrez-Macías, A. M. Rodríguez, and L. Fernández. 
Appendix II. Settings for the best ecological niche models for Anolis guamuhaya based on lowest Akaike's information criterion (AICC). $\triangle A I C$ represents the difference between the AICc score for each model and the AICc score of best model; models with $\triangle A I C<2$ could be considered to have substantial support.

\begin{tabular}{lccccccc}
\hline FC & $\mathbf{R M}$ & $\mathbf{A U \mathbf { C } _ { \text { train } }}$ & $\mathbf{A U \mathbf { C } _ { \text { test } }} \mathbf{\pm} \mathbf{S D}$ & $\mathbf{A U \mathbf { C } _ { \text { diff } }}$ & OR MTP & AICc & $\Delta$ AIC \\
\hline LQ & 1 & 0.938 & $0.940 \pm 0.005$ & 0.025 & $0.227 \pm 0.103$ & 242.49 & 0 \\
LQ & 1.5 & 0.938 & $0.934 \pm 0.009$ & 0.030 & $0.227 \pm 0.103$ & 242.92 & 0.42 \\
L & 1 & 0.937 & $0.940 \pm 0.005$ & 0.024 & $0.273 \pm 0.149$ & 243.50 & 1.00 \\
LQ & 2 & 0.938 & $0.924 \pm 0.001$ & 0.038 & $0.227 \pm 0.103$ & 243.51 & 1.01 \\
LQ & 2.5 & 0.938 & $0.919 \pm 0.002$ & 0.042 & $0.227 \pm 0.103$ & 244.25 & 1.75 \\
L & 1.5 & 0.937 & $0.935 \pm 0.0007$ & 0.028 & $0.227 \pm 0.103$ & 244.30 & 1.80 \\
LQHP & 4.5 & 0.931 & $0.939 \pm 0.02$ & 0.021 & $0.227 \pm 0.103$ & 244.43 & 1.94 \\
\hline
\end{tabular}

Appendix III. Estimates of relative contributions and permutation importance of the six bioclimatic variables selected to build the ecological niche model for Anolis guamuhaya.

\begin{tabular}{lcc}
\hline Variables & Percent contribution & Permutation importance \\
\hline Max. temperature of warmest month (bio 5) & 55 & 0 \\
Mean diurnal range (bio 2) & 18.7 & 39.1 \\
Temperature seasonality (bio 4) & 17.4 & 18.2 \\
Precipitation seasonality (bio 15) & 7.3 & 41.9 \\
Precipitation of driest quarter (bio 17) & 1.5 & 0 \\
Precipitation of the wettest month (bio 13) & 0.1 & 0.9 \\
\hline
\end{tabular}

